\title{
Pendampingan Pola Hidup Bersih Dan Sehat (PHBS) Untuk Menekan Angka Kejadian Covid-19 Pada Kader Wilayah Puskesmas Nguter Sukoharjo.
}

\author{
Siti Ma'rufah ${ }^{1}$, Lilik Wijayanti ${ }^{2}$, Yulia Sari $^{3}$, Widia Susanti ${ }^{4}$, Sigit Setyawan ${ }^{3}$, Sri \\ Haryati $^{3}$, Endang Listyaningsih $\mathbf{S}^{5}$, Sugeng Purnomo \\ 1. Laboratorium Farmakologi, Fakultas Kedokteran, Universitas Sebelas Maret \\ 2. Laboratorium Patologi Klinik, Fakultas Kedokteran, Universitas Sebelas Maret \\ 3. Laboratorium Parasitologi, Fakultas Kedokteran, Universitas Sebelas Maret \\ 4. Bagian Gigi dan Mulut, Fakultas Kedokteran, Universitas Sebelas Maret \\ 5. Laboratorium Histologi, Fakultas Kedokteran, Universitas Sebelas Maret \\ 6. Puskesmas Nguter, Sukoharjo
}

\begin{abstract}
ABSTRAK
Pendahuluan : Covid-19 (Coronavirus disease-19) masih menjadi bahasan yang hangat diberbagai belahan dunia. Kabupaten Sukoharjo, merupakan salah satu kabupaten yang menyumbangkan pasien Covid-19 dengan jumlah saat ini mencapai lebih dari 4300 orang. Berbagai upaya untuk memperlambat laju infeksi dan kematian telah dilaksanakan oleh Pemerintah Sukoharjo dengan "Sukoharjo tanggap COVID-19". Walaupun pemerintah sangat tanggap dalam upaya pencegahan Covid-19 ini, tapi untuk sosialisasi dan pendampingan langsung kepada keluarga belum maksimal, seperti terlihat pada kepatuhan berperilaku hidup bersih dan sehat (PHBS) dengan penerapan protokol kesehatan belum baik. Pengabdian ini bertujuan memberikan pendampingan tentang PHBS serta protokol kesehatan guna pencegahan Covid-19 di Sukoharjo.

Metode: Pengabdian ini akan dilakukan dengan metode HIRARC yaitu Hazard Identification, Risk Assessment, dan Risk Control. Pengabdi memberikan intervensi berupa pendampingan kepada 47 kader masyarakat di wilayah Puskesmas Nguter Sukoharjo.

Hasil dan pembahasan: Hasil posttest menunjukkan peningkatan pengetahuan menjadi 63 dari sebelumnya 56,6. Hampir $85 \%$ peserta pada materi PHBS dan Protokol kesehatan memiliki pengetahuan yang sangat baik.
\end{abstract}

Kesimpulan: Pelaksanaan pengabdian berjalan dengan efektif dengan peningkatan pengetahuan tentang Covid-19, PHBS dan Protokol kesehatan dalam rangka menekan angka penyebaran Covid-19.

Kata kunci : Covid-19; pendampingan; PHBS

\begin{abstract}
Introduction: Covid-19 (Coronavirus disease-19) is still a hot topic in various parts of the world. Sukoharjo Regency is one of the regencies that donated COVID-19 patients with the current number reaching more than 4300 people. Various efforts to slow the rate of infection and death have been carried out by the Sukoharjo government with "Sukoharjo responding to COVID-19". Although the government is very responsive in this effort to prevent COVID-19, socialization and direct assistance to families has not been maximized, as can be seen in the adherence to clean and healthy living behavior (PHBS) with the implementation of health protocols that have not been good. This service aims to provide assistance on PHBS and health protocols to prevent Covid-19 in Sukoharjo.

Method: This service will be carried out using the HIRARC method, namely Hazard Identification, Risk Assessment, and Risk Control. Servants provide intervention in the form of assistance to 47 community cadres in the Nguter Sukoharjo Community Health Center area.

Results and discussion: The posttest results showed an increase in knowledge to 63 from the previous 56.6. Nearly $85 \%$ of participants in the PHBS and health protocol materials have very good knowledge. Conclusion: The implementation of the service runs effectively by increasing knowledge about Covid-19, PHBS, and health protocols to reduce the spread of Covid-19.
\end{abstract}

Keywords : Covid-19; Mentoring; PHBS

Correspondence: Siti Ma'rufah, M.Sc.,Apt, Universitas Sebelas Maret, sitimarufah.sm@gmail.com

Submitted : 07/05/2021 Accepted : 06/06/2021 Published: 31/07/2021 


\section{PENDAHULUAN}

Sejak wabah pertama dilaporkan di Wuhan, Cina pada Desember $2019^{1}$, virus corona (COVID-19) dengan cepat menjadi perhatian global. WHO menyatakan wabah virus sebagai pandemi pada 11 Maret 2020. Saat ini lebih dari 100 juta orang telah terinfeksi COVID-19, dengan lebih dari dua juta kematian di seluruh dunia ${ }^{2}$. Data Covid-19 di Indonesia lebih dari 1 juta ditahun 2021 dengan angka kematian diangka 25.000 orang . Kabupaten Sukoharjo, merupakan salah satu kabupaten yang menyumbangkan pasien Covid-19 dengan jumlah saat ini mencapai lebih dari 4300 orang $^{3}$. Dalam upaya untuk memperlambat laju infeksi dan kematian, pemerintah di kabupaten Sukoharjo telah membentuk tim "Sukoharjo tanggap COVID-19" yang bertugas untuk membagikan 34.500 masker ke masyarakat, penutupan tempat makan, fasilitasi tempat cuci tangan di pasar, Pengadaan rumah sehat Covid-19, tim posko Covid-19 siaga 24 jam, penundaan pelayanan langsung pemerintahan dan pembatalan hajatan masyarakat ${ }^{3}$. Walaupun pemerintah sangat tanggap dalam upaya pencegahan Covid-19 ini, tapi untuk sosialisasi dan pendampingan langsung kepada keluarga belum maksimal, yaitu pada kepatuhan berperilaku hidup bersih dan sehat (PHBS), juga termasuk protocol kesehatan pencegahan covid. Kita ketahui bahwa keluarga merupakan faktor terdekat dalam penularan covid, sehingga menunjukan pentingnya keluarga sebagai fokus dalam pencegahan penyebaran Covid-19.

Untuk mencapai sasaran pembangunan kesehatan pada akhir tahun 2021 telah ditetapkan Rencana Pembangunan Jangka Menengah Daerah (RPJMD) Kabupaten Sukoharjo tahun 2016 - 2021 sebagaimana diatur dalam Peraturan Daerah Kabupaten Sukoharjo Nomor 10 Tahun 2016. Dengan mempertimbangkan perkembangan dan berbagai kecenderungan masalah kesehatan ke depan, mempertimbangkan Visi dan Misi Pemerintah Kabupaten Sukoharjo telah ditetapkan Visi Dinas Kesehatan Kabupaten Sukoharjo yaitu: "Terwujudnya Pelayanan Kesehatan Paripurna Menuju Masyarakat yang Sehat, Sejahtera dan Mandiri“. Puskesmas Nguter Sukoharjo merupakan salah satu pusat pelayanan kesehatan yang membantu dalam upaya pencegahan Covid-19. Dari data persebaran dan jumlah pelayanan kesehatan tingkat pertama dapat diketaui pula mengenai interaksi dengan menggunakan pendekatan model gravitasi dengan pembatasan ganda yang dirumuskan oleh Lee 1997 dalam Tarigan (2010 : 168). Hasil dari perhitungan tersebut yaitu dapat diketahui kecamatan mana saja yang memiliki interaksi rendah, sedang dan tinggi. Interaksi Pelayanan Kesehatan Tingkat Pertama (PKTP) di Kabupaten Sukoharjo tahun 2011 termasuk dalam kategori rendah. Dengan pelayanan puskesmas dalam kategori baik, puskesmas nguter dibantu oleh empat Puskesmas Pembantu (Pustu). Adapun wilayah kerja Puskesmas meliputi semua desa di Kecamatan Nguter, Sukoharjo, dapat dilihat pada Gambar 1. 


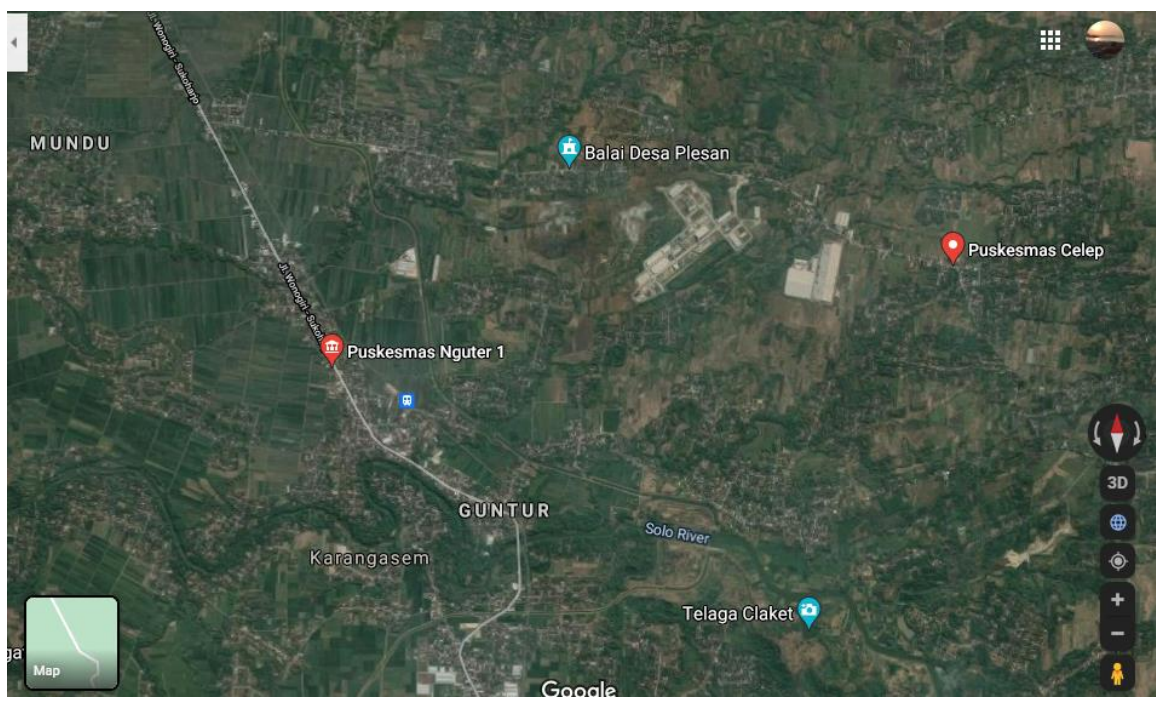

Gambar 1. Wilayah kerja Puskesmas Nguter, Sukoharjo.

Sejak Covid-19 ini puskesmas merasa kuwalahan karena puskesmas memiliki tugas yang komplek dan ini harus dihadapi puskesmas, seperti melakukan prevensi, deteksi dan respon di dalam pencegahan dan pengendalian Covid-19. Hal ini merupakan bagian yang di lakukan agar dapat mengendalikan jumlah kasus. Puskesmas Nguter dituntut harus mampu mengelola, memanfaatkan sumber daya yang dimilikinya secara efektif dan efisien dalam memutus mata rantai penularan, baik di level individu, keluarga dan masyarakat. Hal ini dapat dilakukan melalui kegiatan komunikasi risiko dan KIE, pemberdayaan masyarakat, dan penggerakan peran serta lintas sektor. Puskesmas juga diharapkan melakukan pemberdayaan masyarakat di wilayah kerjanya pada berbagai aspek baik pada sisi prevensi, deteksi dan respon.(kemenkes,2020). Salah satu wujud kinerja tim medis Puskesmas Nguter dalam rangka memutus rantai penularan covid dengan adanya posko Covid-19. Oleh karena itu, pengabdi ingin membantu program pemerintah dengan cara melaksanakan pengabdian yang bertujuan memberikan pendampingan dengan edukasi dan monitoring tentang perilaku hidup bersih dan sehat (PHBS) serta protokol kesehatan guna pencegahan Covids-19 di wilayah puskesmas nguter, Sukoharjo.

\section{METODE}

Metode pengabdian yang akan dilakukan adalah dengan menggunakan metode HIRARC yaitu Hazard Identification, Risk Assessment, dan Risk Control. Pengabdian dilaksanakan pada tanggal 28 April 2021. Subjek pada pengabdian ini adalah kader kesehatan Puskesmas Nguter, Sukoharjo. Instrumen pengabdian dengan menggunakan kuesioner, leaflet dan materi PHBS. Secara lebih detail sebagai berikut.

\section{a. Hazard Identification}

Merupakan tahap awal yang dilakukan untuk identifikasi prevalensi health risk behavior pada keluarga di wilayah Puskesmas Nguter.

\section{b. Risk Assessment}

Dilakukan untuk menilai risiko yang diakibatkan oleh faktor-faktor (health-risk behavior) tersebut, serta menilai prioritas masalah yang harus dikendalikan untuk menurunkan health risk behavior keluarga di wilayah Puskesmas Nguter. 


\section{c. Risk Control}

Merupakan tahap pengendalian yang akan dilakukan dengan menerapkan prinsip digitalisasi informasi, untuk mengendalikan permasalahan health risk behavior pada keluarga. Untuk menyesuaikan dengan program yang akan digunakan sebagai solusi pada pengabdian ini.

Pelaksanaan kegiatan pengabdian masyarakat Riset Group (RG) Tropibio.com berjalan dengan baik dan lancar. Pengabdian masyarakat ini mengangkat tema "PHBS dan Covid-19". Pengabdian dalam bentuk penyuluhan kepada kader puskesmas nguter dengan materi tentang PHBS terkait protokol kesehatan pada masa pandemi Covid-19. Kegiatan tidak hanya sekedar memberikan pengetahuan, melainkan juga memberikan motivasi melalui pendampingan partisipatif agar kader dapat menerapkan PHBS dan protokol kesehatan secara mandiri dalam kehidupan sehari-hari serta diharapkan kader yang merupakan tangan panjang dari puskesmas dalam membantu pendampingan kesehatan masyarakat. Pencegah penularan Covid-19 salah satunya dengan memperhatikan Perilaku Hidup Bersih dan Sehat (PHBS) dalam sehari-hari dilingkungan rumah ataupun diluar rumah.

\section{HASIL DAN PEMBAHASAN}

Salah satu upaya pencegahan penyebaran penyakit termasuk virus Covid 19 adalah dengan penerapan PHBS. Kegiatan tersebut meliputi selalu mencuci tangan dengan baik dan benar dengan menggunakan sabun serta dilakukan pada air mengalir atau menggunakan handsanitizer, selalu memakai masker dengan benar saat berada diluar ruangan atau bersama dengan orang lain, selalu menutup mulut dan hidung saat bersin dengan menggunakan tisu ataupun lengan atas bagian dalam, jaga jarak 1-2 meter, menghindari kerumunan atau berkumpul, jika dari luar segera mandi dan ganti pakaian, dan selalu menjaga kebersihan lingkungan di dalam dan di sekitar rumah. ${ }^{6,7,8,9}$

Kegiatan pengabdian masyarakat ini dihadiri oleh 47 kader dengan protokol kesehatan yang ketat. Selama kegiatan berlangsung, kader sangat antusias dalam menyimak edukasi yang ditampilkan dalam bentuk presentasi power point. Mereka juga interaktif dalam berdiskusi. Pelaksanaan kegiatan dimulai jam 13.00-15.00. Mengingat protokol kesehatan, pelaksanaan dilaksanakan dengan waktu yang sesingkat-singkatnya dan menjaga jarak antara peserta satu dengan peserta lain. Adapun dokumentasi dapat dilihat pada gambar 2-4.

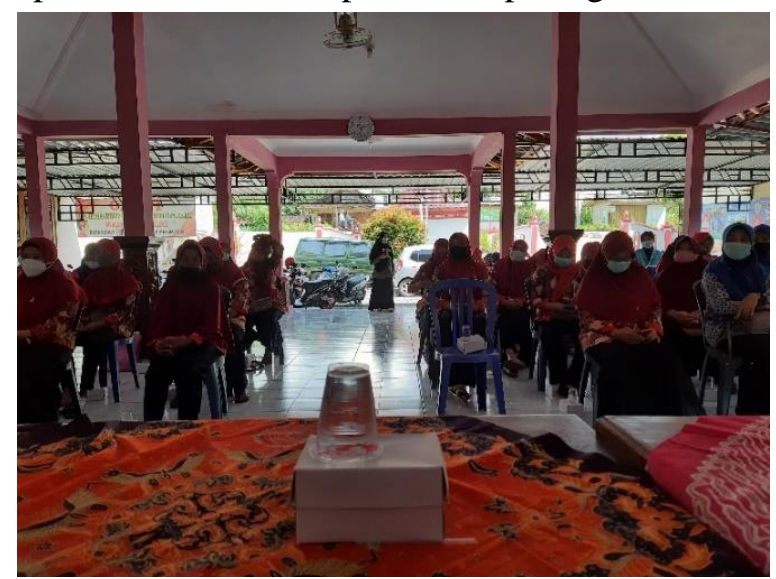

Gambar 2. Pelaksanaan Pengabdian di Wilayah Puskesmas Nguter, Sukoharjo 


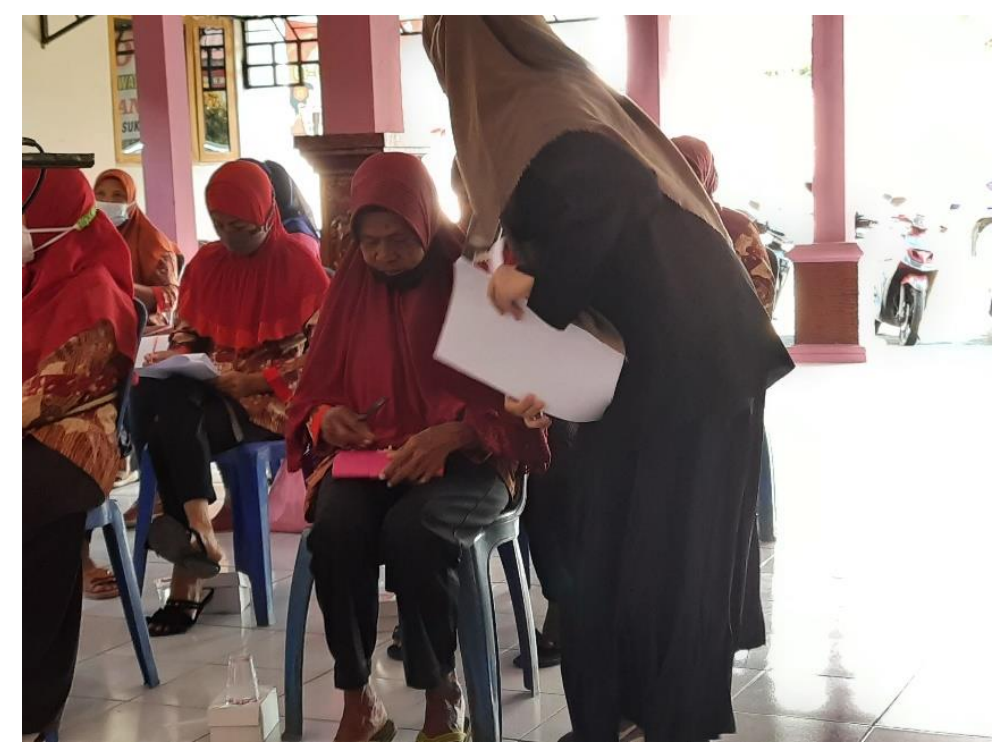

Gambar 3. Pembagian pretest

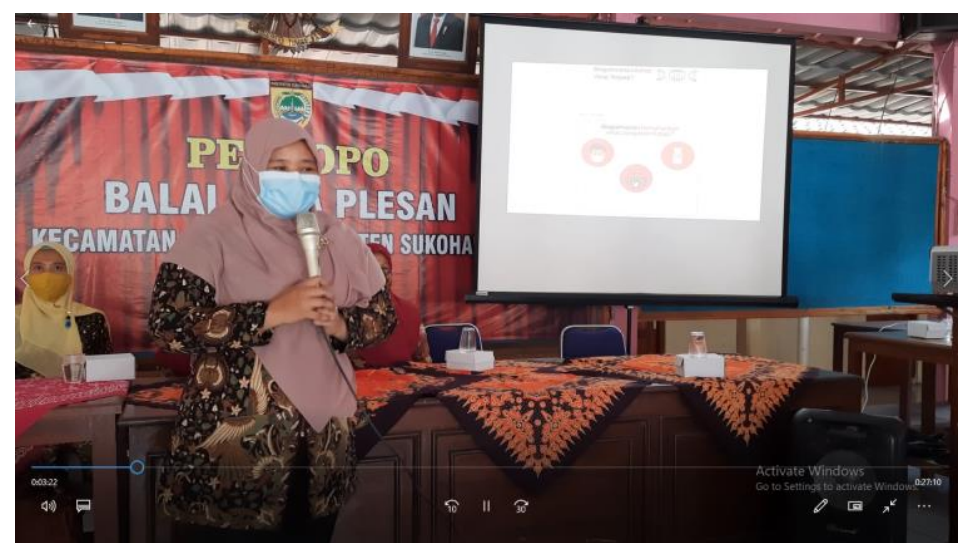

Gambar 4. Pemberian Materi pengabdian 1

Berdasarkan hasil pretes, pengetahuan kader akan PHBS pada masa pandemi memiliki nilai rata-rata 56,6 dengan topik pengetahuan tentang Covid-19, PHBS saat pandemi dan protokol kesehatan di Indonesia. Kesadaran peserta yang kurang tertib dalam menggunakan masker juga dapat dilihat saat pelaksanaan kegiatan (Gambar 3). Terlihat ada peserta yang belum menggunakan masker dengan benar, terlihat menggunakan masker tapi tidak menutup mulut dan hidung. Perilaku masyarakat yang kurang tertib juga muncul pada Putria dkk bahwa ada hubungan yang signifikan antara tingkat pengetahuan dan sumber informasi dengan Penerapan Perilaku Hidup Bersih dan Sehat (PHBS) ${ }^{10}$.

Pretest pengetahuan tentang Covid-19, 34 peserta lebih 50\% telah memiliki pengetahuan akan Covid-19 secara baik. Hal ini didukung dengan nilai yang didapat peserta diantara 75-100, tetapi juga masih ada peserta memiliki nilai 0-50. Dan secara rinci untuk pengetahuan peserta pengabdian terdapat grafik di Gambar 5 . 


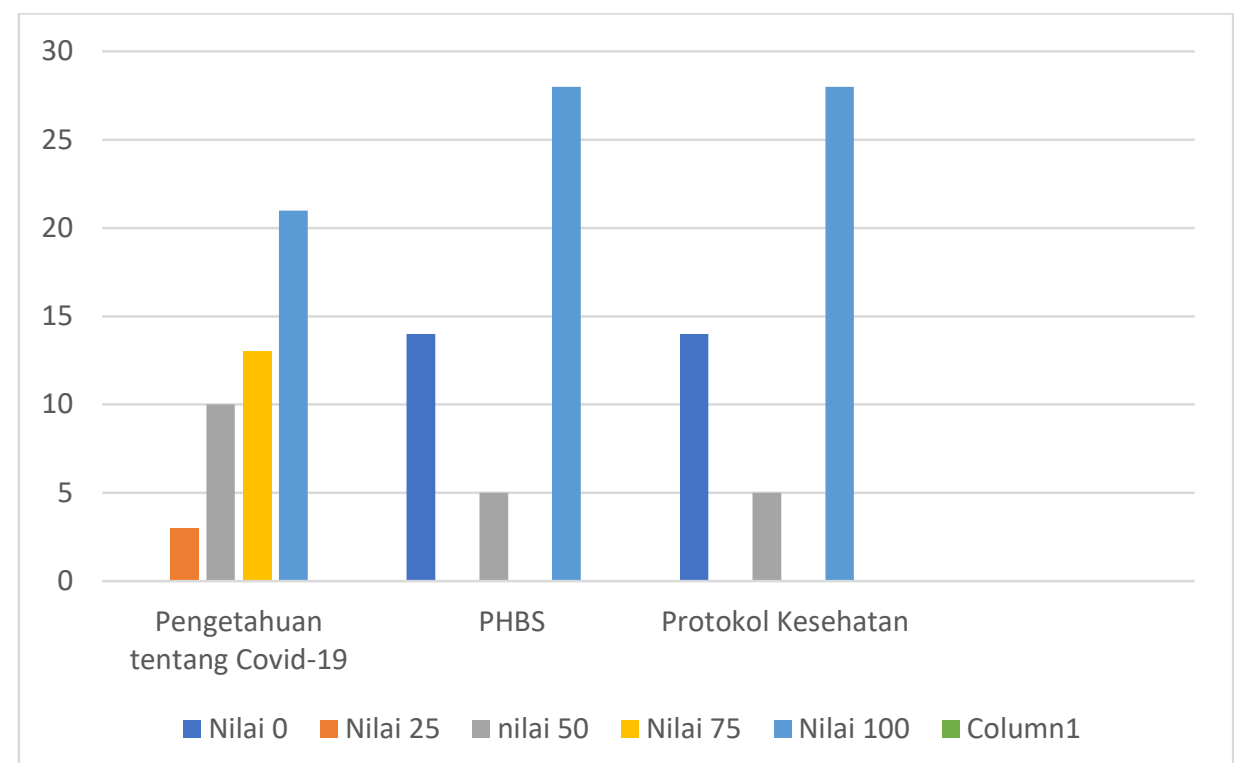

Gambar 5. Grafik hasil pretest tentang Covid-19, PHBS dan Protokol Kesehatan

Berdasarkan hasil posttest, terjadi peningkatan pengetahuan menjadi 63 dari sebelumnya 56,6. Hampir 85\% peserta pada materi PHBS dan Protokol kesehatan memiliki pengetahuan yang sangat baik. Hal ini mengindikasikan bahwa pengabdian yang dilaksanakan efektif dan sesuai dengan data sebelumnya bahwa Promosi kesehatan dalam bentuk penyuluhan secara terus menerus dapat memberikan pengaruh terhadap pengetahuan dan sikap PHBS. 11,12,13. Hasil secara lengkap terdapat pada grafik pada gambar 6.

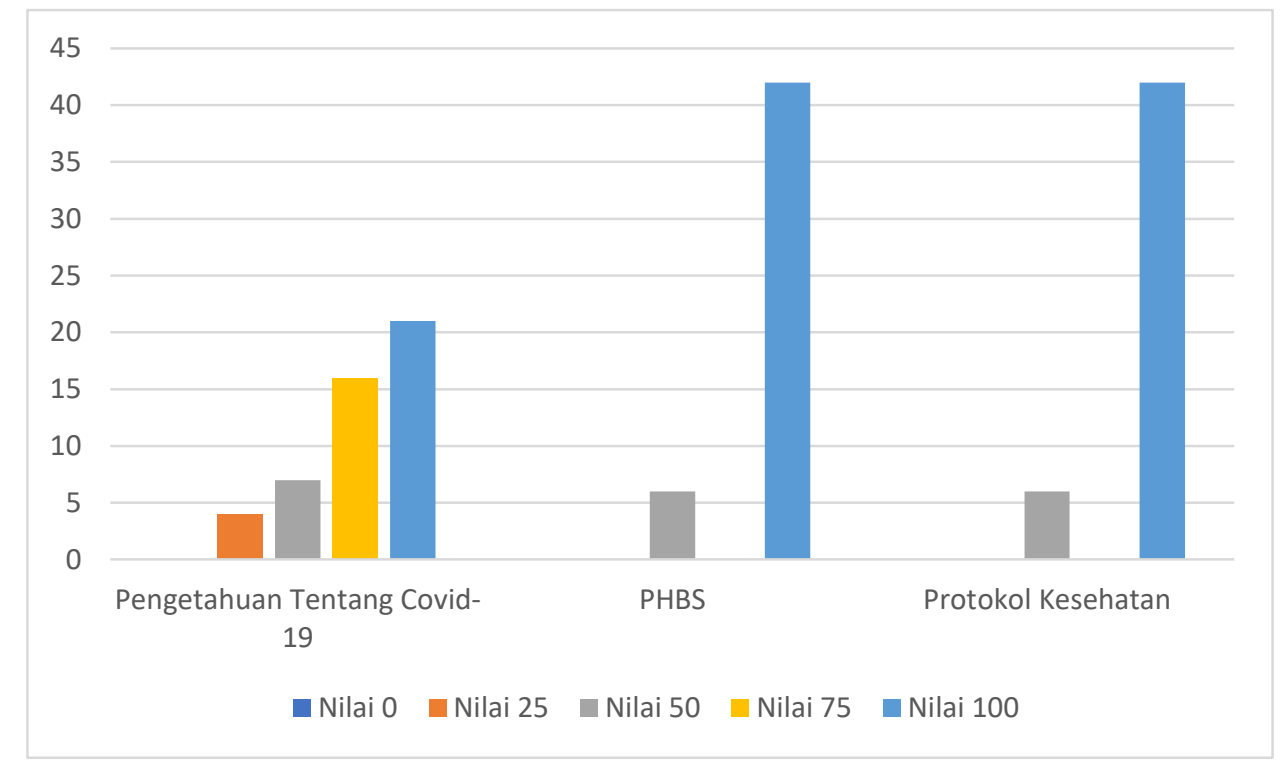

Gambar 6. Grafik hasil posttest tentang Covid-19, PHBS dan Protokol Kesehatan

\section{KESIMPULAN}

Terdapat peningkatan pengetahuan tentang Covid-19, PHBS dan Protokol kesehatan dalam rangka menekan angka penyebaran Covid-19. 


\section{UCAPAN TERIMA KASIH}

Terimakasih kepada Puksesmas Nguter Kabupaten Sukoharjo dan Universitas Sebelas maret yang telah mendukung pengabdian ini.

\section{DAFTAR PUSTAKA}

1. Hui, DS, I Azhar, E, Madani, TA, et al.,2020. The continuing 2019-nCoV epidemic threat of novel coronaviruses to global health - The latest 2019 novel coronavirus outbreak in Wuhan. China. International Journal of Infectious Diseases 91, 264-266.

2. Worldometer.Coronavirus Update (Live).(2021)Retrieved from https://www.wor ldometers.info/coronavirus/

3. Sukoharjo Tanggap Covid-19. Data Sebaran. (2021) https://corona.Sukoharjokab.go.id

4. Badan Pusat Statistik Kabupaten Sukoharjo. Data Sosial dan Kependudukan ( 2021)https://Sukoharjokab.bps.go.id/

5. Dinas Kesehatan Kota Sukoharjo. Puskesamas Bendosari (2021)http://dkk.Sukoharjokab.go.id/

6. Adityo, S. (2020). Coronavirus Disease 2019: Tinjauan Literatur Terkini. Jurnal Penyakit Dalam Indonesia, 7 (1) : 45

7. Chan JFW . (2020). Genomic characterization of the 2019 novel human pathogenic coronavirus isolated from a patient with atypical pneumonia after visiting Wuhan. Emerg Microbes Infect. 2020;9(1):221-365.

8. World Health Organization. (2019). Coronavirus disease 2019 (COVID-19)diakses juni 2021

9. World Health Organization. (2020). Situation Report. Diakses juni 2021

10. Putria Carolina, Meilitha Carolina, Rizki Muji Lestari. (2014). Correlation Of Knowledge And Resources With Application Behavior Clean And Healthy Lifestyle (PHBS) In The Family In The Work Area Pustu Pahandut Seberang Kota Palangka Raya 2016. EnviroScienteae Vol. $12: 330-337$

11. Kurniawan, A., Putri, R. M., \& Widiani, E. (2019). Pengaruh Promosi Kesehatan Terhadap Pengetahuan Dan Sikap Tentang Perilaku Hidup Bersih dan Sehat Kelas IV dan V Sekolah Dasar. Journal Nursing News, 4(1), 100-111. https://doi.org/10.1021/BC049898Y

12. R Roni, S Susmini, R. P. (2018). Peran Promosi Kesehatan Phbs Terhadap Pengetahuan Dan Sikap Remaja Dalam Pencegahan Diare. Nursing News : Jurnal Ilmiah Keperawatan, 3(3).

13. Herniwanti, Octavia Dewi, Jasrida Yunita , Endang Purnawati Rahayu. (2020).Penyuluhan Perilaku Hidup Sehat dan Bersih (PHBS) dan Gerakan Masyarakat Hidup Sehat (GERMAS) kepada Lanjut Usia (LANSIA) Menghadapi Masa Pandemi Covid 19 dan New Normal dengan Metode 3M. Jurnal Abdidas, Volume 1 Nomor 5, $363-372$. 